\title{
Influences of Financial and Non-Financial Compensation on Employees' Turnover Intention in the Energy Sector: The Case of Aramco IPO
}

\author{
Ahmed Alzahrani $^{1}$, \& Ali Shaddady ${ }^{2}$ \\ ${ }^{1}$ MBA student at Business Administration Department,King Abdul-Aziz University, Faculty of Economics and \\ Administration, Business Administration Dep, Jeddah, Saudi Arabia \\ ${ }^{2}$ Finance Department, King Abdul-Aziz University, Faculty of Economics and Administration, Finance \\ Department, Jeddah, Saudi Arabia \\ Correspondence: Ali Shaddady, Finance Department, King Abdul-Aziz University, Faculty of Economics and \\ Administration, Finance Department, Jeddah, Saudi Arabia.
}

Received: March 22, 2021

doi:10.5539/ibr.v14n6p108
Accepted: May 17, 2021

Online Published: May 25, 2021

URL: https://doi.org/10.5539/ibr.v14n6p108

\begin{abstract}
The purpose of this research is to identify the effects of financial and non-financial compensation on employees' turnover intention at Saudi Aramco after an initial public offering (IPO). A questionnaire was used for collecting data from 142 participants, and a simple linear regression model was used to analyse the survey results. This study revealed that the respondents agree that financial compensation is an important factor in their tendency to continue working at their company and that training is another important factor that motivates them to stay. Further, the results show that financial compensation affects employees' turnover intentions, training positively affects their retention at their respective company, and promotion policies correlate with their turnover intentions. The study recommends that companies in the energy sector should give more attention to financial compensation, training, and promotion to motivate employees to remain in their companies. According to the research results, there are positive relationships between retention and continuing in a company based on the independent variables of financial compensation, training, and promotion.
\end{abstract}

Keywords: financial compensation, non-financial compensation, training, promotion, employee turnover

\section{Introduction}

One of the major challenges facing any organisation is its ability to recruit and retain talented employees because the decision to add talent can profoundly affect the organisation's activities and financial path and increase employee turnover (Finnegan, 2010).

The total compensation, both financial and non-financial, that the organisation provides to its employees is related to whether it pays less or more than the wages/compensation prevailing in the market and in its sector. Compensation is also related to the type of employees that an organisation attempts to attract, which, in turn, helps to identify the quality of benefits it can offer to its employees.

Financial benefits refer to the cash funds allocated for salaries and periodic incentives, while non-financial funds are allocated for other benefits. For example, there are companies that provide opportunities and job security, and long-term employment depends more upon allocating a large percentage of the total compensation budget for benefits such as life, sickness, and disability insurance programs, as well as profit-sharing systems. Of course, employees are still eager to receive direct financial compensation.

To draw in and retain the top people, organisations may utilise wages and pay rates as the pay framework adds to making their best offer (Gardner et al., 2004; Judge \& Heneman, 2000). Chelladurai (2006) found that wages and pay rates are two of the essential components that attract attention. Monetary remuneration is the main factor in the pay framework an organisation uses to reward its employees in return for their commitment to work and accomplish organisational objectives (Judge \& Heneman, 2000, Newman \& Milkovich; 2004). Based on this methodology, employees in any organisation seek a remuneration framework that is clear and straightforward.

This approach may conflict with need theories of motivation, which focus on the environmental factors or 
non-financial compensation that changes over time or place and do not focus solely on financial compensation. In other words, motivation theories focus more on psychological elements (Ramlall, 2004).

There is a debate about the factors that motivate employees, whether financial or non-financial, that has intensified in research on compensation's influence on employees' turnover intentions, particularly when organisations are facing a significant change, such as going public (i.e., listed on a stock market).

Our study is distinct from other studies because it sheds light on the organisational problems of a lack of financial and non-financial compensation, a lack of interest in training, and an absence of a clear system for promotion, which may lead some employees to leave and search for alternative employment that offers these advantages. This has made financial and non-financial compensation among the factors that affect employee turnover or retention, regardless of the work environment, particularly in the energy sector after an initial public offering (IPO). In this respect, Saudi Aramco provides the best environment in which to conduct our study, as it is one of the largest energy companies in the world, with approximately 79,000 employees ${ }^{3}$ and the largest IPO in the world ${ }^{4}$.

Indeed, the problem of low retention rates has always been a challenge for employers. The scholarly debate about employee retention arose in the 20th century when scientists and psychologists began to identify the various reasons that affect employees' level of interest in their jo, and their possible alternative opportunities (Rowland \& Ferris 1981).

Consequently, financial compensation in the form of salaries, and non-financial compensation, such as training and promotion, play important roles in motivating employees to remain with their organisations. Every employee wants to continue with a company that provides good training, a suitable financial system, and standards of promotion that meet his/her ambition to reach a good job level.

The study revealed interesting findings about financial compensation's significant role in employees' turnover intention, particularly after an IPO. Further, the study found a correlation between non-financial compensation (such as promotion and training) and employees' turnover intention.

Along these lines, this paper attempts to provide an avenue for examining the elements that enhance employees' turnover in the energy sector via using intrinsic motivation factors, such as financial and non-financial compensation. This paper might help managers to identify their workers' needs so that relevant programs can be designed to motivate and lead them towards achieving their desired job performance. It may also assist in developing a more effective compensation system.

The remainder of the paper proceeds as follows. Section 2 presents the theoretical framework and literature review. Section 3 describes the methodology and data analysis. The results and discussion are presented in section 4 , while section 5 offers a conclusion.

\section{Literature Review and Theoretical Framework}

\subsection{Theoretical Background and Variables Selection}

The direct relation between the independent variables (financial and non-financial compensation) and the dependent variable (employees' intention) was measured using the theoretical framework. The fluctuation in oil prices and the present uncertainty directly affected the choice of these variables. Some variables were not included in the model, such as the work environment, because changes in oil prices do not affect them significantly. To be clear, the relation between the workers' behaviour and the variables investigated is the focus of this study.

Based on the comprehensive literature review below, the researcher developed the following theoretical framework for the study. 


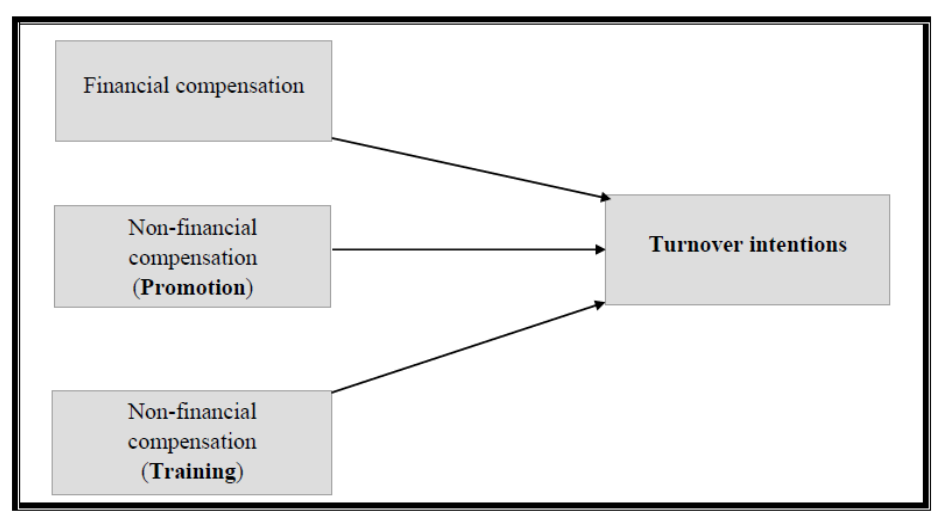

Figure 2.1. Theoretical Framework

\subsection{Literature Review}

This section is divided into two parts: the first reviews previous studies related to the research, and the second focuses on the theoretical framework.

Palwasha et al. (2018) inspected the effects of planning, improvement, and supervisors' support of employees and explored the work environment's coordinating effects on these three elements. The data were accumulated using a survey. The model size was 250 workers from government schools in Pakistan, and the examination accepted the PLS route shown in the data assessment. The results showed that the arrangement, progression, and chairmen's assistance had an enormous positive relationship with the agents' support. Moreover, the results similarly revealed that the work environment coordinated the association among planning and progression, administrators' assistance, and agents' upkeep.

Mardiyanti et al. (2018) investigated the association between workers' satisfaction with, and acceptance of, work-life balance policies (WLBPs) in the relatively unresearched Philippine setting. Their findings showed that the factors directly related to workers' obligations were (1) their overall satisfaction with WLBPs; (2) their satisfaction with the specific WLBPs of prosperity and prosperity; and (3) the WLBPs of compensatory personal time, childcare system, medical service benefits, and paid leave.

Saira Yousaf et al.'s (2014) study endeavoured to recognise monetary and non-monetary compensation as influencing the inspiration of workers in associations. The study embraced subjective and quantitative exploration strategies in an overview directed by Astro Films (PVT) in Lahore City, Pakistan.

A poll was created to assess the representatives working in this association. Semi-organised meetings were directed at getting more knowledge. The research uncovered the various variables that influence representatives' monetary and non-monetary benefits. Monetary benefits are significant for inspiring representatives in agricultural nations like Pakistan, where the increases in monetary are so high that individuals are attempting to hold their societal positions so that non-monetary benefits' significance is not recognised. The research gave a premise for comprehending the issues of workers' inspiration in associations.

Ammoura (2014) created a questionnaire to study the moral factors among Syriatel Company employees, particularly concerning the phenomenon of job burnouts, if any, and the extent of their ability to achieve a balance between work and life, as well as their awareness of organisational fairness within the company. In addition to specifying the type and the significance of the statistical relationship between job burnouts and turnover intentions, the work-life balance and perceived organisational justice were investigated. The sample size was 209 workers at various job levels in the company.

Ammoura (2014) found a significant relationship between each of the stepwise combinations that established the effects of career and perceived distributive and procedural justice, on the one hand, and turnover intentions on the other. This supported two of the research hypotheses, while the hypothesis related to the association between work-life balance and turnover intention was rejected.

The results of the study concerning the moral factors' effect showed that job burnout had the most influential and statistically significant effect on the employees' turnover intentions. This confirms the results of previous studies, while there was no statistically significant effect on the turnover intentions of workers' ability to achieve a work-life balance. 
Palwasha et al. (2017) explored the connection between monetary pay and non-monetary pay, like advancement openings and representative maintenance, and utilised an overview to gather information on 220 employees working in open area colleges in Pakistan. A relapse model was utilised to dissect the information. The outcomes uncovered that remuneration and advancement openings had a critical connection with representatives' maintenance. Further, the outcomes exhibited that the workplace directed the relations among remuneration and representative maintenance and advancement openings and worker maintenance.

Wright et al.'s (1994) study indicated that human resource management practices allow organisations to mould employees' views, opinions, attitudes, and behaviour, and their actions and reactions within the organisation. Two primary factors contribute to turnover: controllable ones and uncontrollable ones (Peterson, 2004). The organisation's HR staff/employers manage the controllable factors (Alam, 2015), which involve internal HR operations and practices, such as recruitment, compensation, induction, selection, training, career progression, performance evaluation, and working environment (Bader et al., 2015). In contrast, uncontrollable factors include employees' demographics and psychographics, as well as the social, technological, political, and economic environments surrounding an organisation that may affect employee turnover (Boxall, Hutchison, \& Wassenaar, 2015). Fortunately, internal HR management (HRM) is included in an organisation's controllable practices, as it can reduce employee turnover (Boxall et al., 2015). However, organisations that are unable to address their employee turnover rate may face serious threats to their productivity and creativity (Balčiūnaitienè et al., 2015).

Employees' recruitment, selection, and hiring are all parts of the first and most critical stage that affects employees' turnover intentions and turnover in the long run (Chan et al., 2017; Peltokorpi et al., 2015).

During this process, hiring motivated and committed talent not only adds value for the organisation but also allows it to retain these employees (Du Preez \& Bendixen, 2015). If this process is transparent, the likelihood that employees will act on their turnover intentions is very low because they feel empowered and encouraged to work in a transparent environment. Employees recruited on merit are talented and more likely to remain with their employers because they believe that the organisation values their talents and skills (Bader et al., 2015). Therefore, the organisation recruited them because it would gain significant benefits by adding value to the organisation. Moreover, different research studies have shown that those employers who conduct realistic job reviews have more committed and satisfied employees who serve as an example for new talent and increases their job retention (Mostafa et al., 2015). Therefore, organisations must focus on selecting the right personnel (Yamao \& Sekiguchi, 2015).

Training and development combined are the second factor that impacts agents' turnover that, because of specialist turnover, prevents organisations from developing their delegates, as they will be based mainly on searching for capacity rather than developing the capacity they have, which furthermore negatively impacts their flexibility (Neves et al., 2018).

Planning and headway improve an organisation's versatility as it urges labourers to remain by promising a progression. Plus, giving more improves their agents' capacities, data, and abilities (Mansoor et al., 2015), and they can fulfil their positions even more effectively. When delegates display improvements due to their arrangement, they feel that trying genuinely and being motivated for their supervisors causes them make and achieve their calling advancement (Chan \& Mai, 2015). Further, improved openings in organisations often favour the supervisors, as their labourers are convinced to be more helpful, which results in benefits. In this cooperation, the likelihood that a specialist will remain with an organisation is augmented as well (Jehanzeb et al., 2015). Considering the capacities acquired and dominated, she or he will undoubtedly make headway that directly affects various levels of earnestness.

Compensation is the third factor that affects employees' motivation and turnover intentions significantly (Kuvaas et al., 2018). There are two forms of compensation: extrinsic financial rewards and intrinsic non-monetary rewards (Katsikea et al., 2015). Extrinsic rewards are referred to as tangible benefits, including salary, remuneration, and bonuses, while intrinsic rewards (also referred to as intangible benefits) include healthcare, fringe benefits, and other perks (Ghosh \& Gurunathan, 2015). Lau et al. (2016) found that compensation policies are associated directly and significantly with employees' turnover intentions, a finding that social exchange theory also supports (Cropanzano \& Mitchell, 2005; Prooijen \& Sleebos, 2015).

\subsection{Employee Turnover}

Employee turnover is defined as situations in which employees leave the organisation for any number of reasons, and this affects the organisation adversely concerning overall expenditures and the ability to provide the minimum services required (Yankeelov et al., 2009) Various scholars have defined employee turnover differently. 
However, the general meaning of the construct remains similar. According to Jacobs and Roodt (2007), intentional or deliberate turnover is an individual's decision to quit his/her present job. Employee turnover is a ratio comparison of the number of employees who need to be replaced within a specific time to the mean of the total workforce (Shukla \& Sinha, 2013). Employee turnover refers to the total number of employees who move in or out of the organisation (Chruden \& Sherman, 1972), while Mobley (1982) referred to employee turnover as an individual's discontinuation of employment in a firm from which she/he was receiving monetary compensation for services.

When employees leave their organisation, it may affect not only the organisation adversely but also the workforce. Because of its depressing influence, employee turnover has been a topic that has attracted significant attention from scholars and managers.

Delegate support, routinely assessed by specialist turnover and labourers' misfortune (Hausknecht et al., 2008; Kar et al., 2011), is the issue of having labourers' organisations, rather than having employees leave to search for their elective business. This has a more unmistakable effect when their motivation behind leaving is to move to another challenging undertaking. Kuvaas and Dysvik (2009) suggest that employees have an advantage when they get non-money-related compensation, such as ready job openings, and become stronger as socially prodded employees who are set up to utilise their efforts to help their organisations.

In any case, little is known inside the current expounding on the components that add to delegates' decision to remain with their endeavours (Hausknecht et al., 2008), notwithstanding that their points of view toward planning (Bartlett, 2001) and its practicality (Kontoghiorghes \& Bryant, 2004) have been found to be associated unequivocally with definitive obligation (Igbaria \& Greenhaus, 1992; Smeenk et al., 2006).

Chandler and McEvoy (2000) and Dalziel (2010) saw that endeavours that put assets into non-financial compensation are setting up their labourers and are busy with standard execution assessment. According to Dalziel (2010), if an endeavour offers a learning environment and has ways to keep staff improving dramatically, then the staff is developing personnel and helping them to achieve.

\subsection{Employee Retention}

Employee retention is a cycle whereby an organisation builds up an environment that urges agents to stay for longer periods (Singh \& Dixit, 2011), and this is seen as a fundamental method to achieve a higher ground in the business community (Walker, 2001). Most organisation today are managing the issue of agent upkeep. Using capable staff for this work is critical for an organisation, as retaining them is crucial because replacing them increases operational costs to fill openings and train new specialists (Ghansah, 2011).

A couple of specialists have addressed the importance of agents' upkeep (Walker, 2001; Zaffane, 1994). Carney (1998) found that correspondence is a crucial factor in holding onto labourers. Kwenin et al. (2013) investigated the effect of HRM procedures, work satisfaction, and grants on agents' upkeep. They assembled data from 142 respondents in Vodafone Ghana Limited and determined that there is a colossal connection between HRM systems, work satisfaction, benefits, and delegates' upkeep. Further, Zareen et al. (2013) examined the association among upkeep and execution and found that they are associated emphatically.

\subsection{Financial Compensation}

Compensation is a key element in retaining employees in all sectors, whether governmental or private. Ichniowski et al. (1997) demonstrated that compensation helps increase retention and reduces absenteeism. They also emphasized that compensation is the principal factor in retaining employees for a longer period.

Remuneration is the main feature of compensation that affects employee retention and attractiveness to stay (Williams \& Dreher, 1992; Khalid \& Nawab, 2018). It's a fact that when organisations do not provide adequate compensation, employees leave.

Past examinations show the effect of delegate upkeep (Irshad, 2000), and the results uncovered an immense association between the financial and not financial compensation, which Ramlall's (2003) results proved. Further, Nawab and Bhati (2013) and Saeed et al. (2013) found a strong association between pay and specialist support.

\subsection{Non-financial Compensation}

\subsubsection{Training}

Labourers have opportunities to acquire and provide huge resources such as data and capacities offered by Training and Development (T\&D) (Koster et al., 2011). This non-financial compensation is a crucial technique for agent upkeep, as it inspires strong responsibilities on labourers' part to repay the relationship for placing assets into their own and work progressions (Lee \& Bruvold, 2003). 
It is therefore imperative to isolate the levels of examination while looking at the effects of HRM practices on specialist results, similar to upkeep (Wright \& Boswell, 2002; Wright \& Nishii, 2007). Various people who execute the HRM division's practices and work consistently with the staff acknowledge that the practices may mirror the organisation's key HRM points (Zewailet al., 1998).

Delegates see and partner with these HRM practices in different ways, depending on a blend of factors similar to experiences and prior qualities. All of them present the reasons behind the organisation's approaches and practices (Nishii et al., 2008). This examination revolves around clear T\&D, as it is this individual perspective on HRM practices that basically affects agents' mindsets and practices (Guest, 2002).

\subsubsection{Promotion}

Campbell (2008) reported that such non-financial compensation as a promotion refers to transferring an individual from one job to another, which requires him/her to accept greater responsibilities in return for an increased salary and authority, provided that the employee accepts this transfer and acknowledges that it indicates appreciation on the part of the organisation for his/her efforts during the period of service and provided that the conditions to promote the employee are met. Abu Bakr (2006) added that promotion is defined sometimes as a transfer that includes an individual's reassignment to another job that offers higher pay and more benefits, or more importance, or all of these benefits combined. Promotions give job satisfaction to employees that result in increased productivity along with efficiency and efficacy as well (Ji Sung \& Senryu, 2017).

On the other hand, the promotion may not result in a wage increase if it is from one job to another at the same level (Musa, 2002). To ensure the acceptance of any promotion or promotion program and commitment to its implementation, Yousaf et al. (2014) stated that management and workers must agree upon what promotion means according to the following: That it is a transfer from one job to another vacant job, and that the administration has decided to fill the position from among the organisation's employees. Further, it must be understood that the duties and responsibilities between the current position and the unoccupied position differ and that this promotion will result in an increase in present or future wages.

The evidence indicates that if their criteria are clear, promotions can help organisations, particularly oil companies, retain their workers because the opportunity for promotion motivates individuals to invest more effort, demonstrate more discipline at work, and increase production.

Job turnover affects the organisation and the labor differences and generally disrupts society. The adverse effects of employee turnover are the high cost of replacing the qualified lost labor, in addition to a defect in the social structure. The positive effects of employee turnover are the low cost of labor, the elimination of lost competencies, and the sharing of new information and technology. Cotton and Tuttle (1986) have shown that job turnover is the likelihood of remaining in an organisation, while Meyer et al. (1994) defined job turnover as the individual's desire to search for another employer.

\section{Methodology and Data Analysis}

The study used statistical methods to analyse the research data and test the hypotheses. Simple linear regression was adopted to examine the relation between the dependent variable and independent variables, and the results obtained helped test the research hypotheses and answer the research questions.

\subsection{Study Population}

The research population was comprised of employees working in a petroleum company in Saudi Arabia. The study population was selected randomly to collect accurate data. A self-administrated questionnaire was used to collect the primary data from the respondents working in the company because it is a large company and the results may apply to other energy companies.

\subsection{Research Design and Sample Size}

This was a quantitative research study that examined the effects of financial compensation and non-financial compensation (promotion and training) on employees' turnover intention in the energy sector.

A simple random sampling technique was adopted to select the research sample, which was representative of the population overall and included 142 participants.

The study used a questionnaire as the data collection tool that was designed electronically using Google forms. The questionnaire asked various questions related to the research, including the effects of financial and non-financial compensation on employees' turnover intention in the petroleum company studied. The questionnaire was distributed to the sample selected to collect the data. The researcher constructed the final questionnaire and managed the process of sending and receiving the participants' completed questionnaires. 


\subsection{Research Hypotheses}

The study is based on the following hypotheses:

$\mathrm{H}_{1}$ : Financial compensation affects employees' turnover intentions.

$\mathrm{H}_{2}$ : Training and development have a positive influence on employees' turnover intentions.

$\mathrm{H}_{3}$ : The promotion policy is correlated with employees' turnover intentions.

\subsection{Statistical Procedures}

The study adopted many statistical methods, including descriptive statistics (frequencies, percentages, standard deviations), and Chi-squared tests to test the study's hypotheses. Regression analysis was performed as well to identify the relation between the dependent variable and independent variables.

\subsection{Reliability Test}

To support the authenticity of the proposed model, a pretest and a pilot outline were reviewed before the main investigation. To ensure the contents' authenticity, experienced representatives in business research explored a lot of studies that indicated a reliance upon past assessments. Further, the study's points and authenticity were affirmed through gatherings with experts in the business. A pilot study was coordinated using the basic survey techniques, and 15 agents participated in the web study. The eventual outcome of the Cronbach's alpha test was 0.92 , which confirmed that the survey results had high quality and authenticity.

\subsection{Data Analysis}

Initially, the following descriptive statistics were computed: Arithmetic means and percentages used to determine the respondents' attitudes toward, and opinions about, the survey's questions. A descriptive survey was conducted for the three research factors. Regression analysis and correlation were performed to determine the association between the dependent variable and the independent variables.

The frequency and percentage distributions of males and females were determined, and the results are shown in Table 1.

Table 1. Respondents' distribution by gender

\begin{tabular}{|l|c|c|}
\hline Gender & Frequency & Percentage \\
\hline Male & 118 & $83.1 \%$ \\
\hline Female & 24 & $16.9 \%$ \\
\hline Total & 142 & $100.0 \%$ \\
\hline
\end{tabular}

Table 2 shows the frequency and percentage distribution according to age and indicated that the workers in the company are a suitable age for this research.

Table 2. Respondents' frequency and percentage distribution by age

\begin{tabular}{|l|c|c|}
\hline Age Group & Frequency & Percentage \\
\hline $18-24$ & 3 & $2.1 \%$ \\
\hline $25-34$ & 67 & $47.2 \%$ \\
\hline $35-44$ & 46 & $32.4 \%$ \\
\hline $45-54$ & 26 & $18.3 \%$ \\
\hline Total & 142 & $100.0 \%$ \\
\hline
\end{tabular}

The results in Table 3 show the frequency and percentage distribution of the respondents according to their educational level. 
Table 3. Respondents' frequency and percentage distribution by educational level

\begin{tabular}{|l|c|c|}
\hline Age Group & Frequency & Percentage \\
\hline Secondary & 26 & $18.3 \%$ \\
\hline University & 81 & $57 \%$ \\
\hline Master's & 32 & $22.5 \%$ \\
\hline Ph.D. & 3 & $2.1 \%$ \\
\hline Total & 142 & $100.0 \%$ \\
\hline
\end{tabular}

The results in Table 4 illustrate the respondents' frequency and percentage distribution according to position.

Table 4. Respondents' frequency and percentage distribution by position

\begin{tabular}{|l|c|c|}
\hline Position & Frequency & Percentage \\
\hline Professional & 36 & $25.4 \%$ \\
\hline Administrative & 53 & $37.3 \%$ \\
\hline Professional 2 & 19 & $13.4 \%$ \\
\hline Middle management & 27 & $19.0 \%$ \\
\hline Senior management & 7 & $4.9 \%$ \\
\hline Total & 142 & $100 \%$ \\
\hline
\end{tabular}

Table 5 shows the respondents' frequency and percentage distribution according to years of experience, which indicated that the company's employees have considerable experience.

Table 5. Respondents' frequency and percentage distributions according to years of experience

\begin{tabular}{|l|c|c|}
\hline Years of Experience & Frequency & Percentage \\
\hline $3-5$ years & 13 & $9.2 \%$ \\
\hline $5-10$ years & 51 & $35.9 \%$ \\
\hline $10-15$ years & 37 & $26.1 \%$ \\
\hline 15 years and more & 41 & $28.9 \%$ \\
\hline Total & 142 & $100.0 \%$ \\
\hline
\end{tabular}

Table 6 shows the respondents' distribution according to income.

Table 6. Respondents' frequency and percentage distribution according to income

\begin{tabular}{|l|c|c|}
\hline Income & Frequency & Percentage \\
\hline $800-1000 S R$ & 43 & $30.3 \%$ \\
\hline $10000-15000 S R$ & 56 & $39.4 \%$ \\
\hline $15000-20000 S R$ & 23 & $16.2 \%$ \\
\hline $20000-30000 S R$ & 13 & $9.2 \%$ \\
\hline More than 30000SR & 7 & $4.9 \%$ \\
\hline Total & 142 & 100.0 \\
\hline
\end{tabular}

The results shown in Table 7 indicate that the respondents' agreement with the recipients of the financial compensation axis statements was positive and high, and the percentages of agreement with the negative phrases were small. This indicates financial compensation's positive influence on the company employees' retention. 
The results of the Chi-squared test indicated that there were no statistically significant differences among the respondents' opinions, which supports the first hypothesis that states: Financial compensation affects employee turnover intentions.

Table 7. Descriptive statistics for financial compensation

\begin{tabular}{|c|c|c|c|c|c|c|c|c|c|}
\hline Statement & $\begin{array}{c}\text { Strongly } \\
\text { agree }\end{array}$ & Agree & $\begin{array}{c}\text { Neither } \\
\text { agree nor } \\
\text { disagree }\end{array}$ & Disagree & $\begin{array}{l}\text { Strongly } \\
\text { disagree }\end{array}$ & Mean & Rank & $\begin{array}{c}\text { Chi-squa } \\
\text { red }\end{array}$ & $p$-value \\
\hline $\begin{array}{lr}\text { Satisfied with } \\
\text { my wages and } \\
\text { benefits after } \\
\text { IPO }\end{array}$ & $16.9 \%$ & $38 \%$ & $12.7 \%$ & $26.1 \%$ & $6.3 \%$ & 3.30 & 4 & 43.4 & 0.00012 \\
\hline $\begin{array}{l}\text { I feel good about } \\
\text { my chance to } \\
\text { increase my } \\
\text { salary after IPO }\end{array}$ & $19 \%$ & $41.5 \%$ & $14.8 \%$ & $15.5 \%$ & $9.2 \%$ & 3.45 & 3 & 44.7 & 0.0001 \\
\hline $\begin{array}{l}\text { I feel I am } \\
\text { charging a } \\
\text { reasonable } \\
\text { amount for the } \\
\text { work I do after } \\
\text { IPO }\end{array}$ & $12.7 \%$ & $42.3 \%$ & $15.5 \%$ & $18.3 \%$ & $11.3 \%$ & 3.26 & 5 & 46.1 & 0.00003 \\
\hline $\begin{array}{l}\text { The material } \\
\text { incentives I get } \\
\text { are appropriate } \\
\text { after IPO }\end{array}$ & $11.3 \%$ & $37.3 \%$ & $23.2 \%$ & $18.3 \%$ & $9.9 \%$ & 3.22 & 6 & 34.9 & 0.0001 \\
\hline $\begin{array}{l}\text { The company is } \\
\text { interested in } \\
\text { career } \\
\text { development } \\
\text { after IPO }\end{array}$ & $12.7 \%$ & $35.9 \%$ & $23.9 \%$ & $14.8 \%$ & $12.7 \%$ & 3.21 & 7 & 28.6 & 0.0000 \\
\hline $\begin{array}{l}\text { Financial } \\
\text { compensation is } \\
\text { the most } \\
\text { important factor } \\
\text { in continuing } \\
\text { with the } \\
\text { company after } \\
\text { IPO }\end{array}$ & $40.1 \%$ & $44.4 \%$ & $6.3 \%$ & $8.5 \%$ & $0.7 \%$ & 3.15 & 8 & 120.1 & $\begin{array}{c}0.00001 \\
4\end{array}$ \\
\hline $\begin{array}{l}\text { The work } \\
\text { environment is } \\
\text { not as important } \\
\text { as the monetary } \\
\text { compensation } \\
\text { after IPO }\end{array}$ & $9.9 \%$ & $18.3 \%$ & $14.1 \%$ & $37.3 \%$ & $20.4 \%$ & 3.59 & 2 & 313. & 0.00003 \\
\hline $\begin{array}{l}\text { The financial } \\
\text { compensation } \\
\text { provided by the } \\
\text { company is } \\
\text { attractive to join } \\
\text { the company } \\
\text { after IPO }\end{array}$ & $21.8 \%$ & $45.1 \%$ & $18.3 \%$ & $12.7 \%$ & $2.1 \%$ & 3.72 & 1 & 71.5 & 0.00001 \\
\hline
\end{tabular}

Table 8 shows the descriptive statistics for financial compensation. The statements were ranked according to the mean of the respondents' answers. The statement, "The financial compensation provided by the company is attractive to join the company," ranked first with a mean of 3.72. This result indicated that the respondents agree with financial compensation's important role in employees' retention. This was followed by the statement, "The work environment is not as important as the monetary compensation is," which ranked second with a mean of 3.59. The statement, "I feel good about my chance to increase my salary," ranked third with a mean of 3.4.

The statement, "Satisfied with my wages and benefits," held the fourth rank with a mean of 3.30, which reflected the employees' satisfaction with their salaries and benefits. The statement, "I feel I am charging a reasonable amount for the work I do," ranked fifth with a mean of 3.26. The statement, "The material incentives I get are 
appropriate," ranked sixth with a mean of 3.22, followed by the statement, "The company is interested in career development," which ranked last with a mean of 3.15. However, these ranks did not differ greatly.

\section{Regression Analysis of Dependent Variable and Financial Compensation}

A simple linear regression was applied to the data collected, in which:

$\mathrm{Y}=$ is the dependent variable (retention/continue with the company)

$\mathrm{X} 1 \mathrm{l}$ the first independent variable (financial compensation)

Table 8 shows the results of the regression, and the relation between the dependent variable and the first independent variable, financial compensation.

The results indicated that financial compensation affects retention and continuing with the company positively and significantly, as the correlation coefficient was 0.49 . The results of a $t$-test confirmed the association between the two variables, which supports the first hypothesis.

Table 8. Regression analysis of the effect of financial compensation

\begin{tabular}{|c|c|c|c|c|c|}
\hline $\mathbf{B}_{\mathbf{0}}$ & $\mathbf{B}_{\mathbf{1}}$ & $\mathbf{r}$ & $\mathbf{R}^{\mathbf{2}}$ & $\boldsymbol{t}$-value & $\boldsymbol{p}$-value \\
\hline 23.2 & 0.36 & 0.49 & 0.25 & 16.5 & 0.0015 \\
\hline
\end{tabular}

Table 9 shows the results of the second factor, training. The key statement, "Training is one of the important factors to keep my job going," has a mean of 4.23. This result indicates that training is a crucial motivating element in employees' retention. The statement, "Training programs offer many benefits for trained employees," ranked second with a mean of 4.11. This showed training programs' importance in employees' development, and that they should be regular and diverse to achieve benefits. The statement, "The company seeks to develop the skills of its employees," ranked third with a mean of 3.49.

The statement, "There are various training programs in the company," ranked fourth with a mean of 3.46, while the statement, "Employees apply what they learn in training programs," ranked fifth with a mean of 3.44. The statement, "The company is keen to train all employees in different departments," ranked sixth with a mean of 3.32. The statement, "There is fairness in distributing training opportunities to the employees of the company," ranked last with a mean of 3.02 .

The results shown in Table 9 indicate that the percentages of the respondents' agreement with the positive training factor statements were higher than that with the negative phrases. This indicates that training affects the employees' retention in the company positively.

The results of the Chi-squared test showed that there were no statistically significant differences between the respondents' opinions, which supported the second hypothesis, "Training and development influence employees' turnover intentions." 
Table 9. Descriptive statistics of training

\begin{tabular}{|c|c|c|c|c|c|c|c|c|c|}
\hline Statement & $\begin{array}{c}\text { Strongly } \\
\text { agree }\end{array}$ & Agree & $\begin{array}{c}\text { Neither } \\
\text { agree nor } \\
\text { disagree }\end{array}$ & Disagree & $\begin{array}{l}\text { Strongly } \\
\text { disagree }\end{array}$ & Mean & Rank & $\begin{array}{l}\text { Chi-squa } \\
\text { red }\end{array}$ & $\begin{array}{c}p \text {-valu } \\
\text { e }\end{array}$ \\
\hline $\begin{array}{l}\text { Training is one of } \\
\text { the important } \\
\text { factors to keep my } \\
\text { job going after IPO }\end{array}$ & $37.3 \%$ & $51.4 \%$ & $7.7 \%$ & $3.5 \%$ & - & 4.23 & 1 & 69.5 & 0.0001 \\
\hline $\begin{array}{l}\text { There are various } \\
\text { training programs in } \\
\text { the company after } \\
\text { IPO }\end{array}$ & $17.6 \%$ & $40.1 \%$ & $19 \%$ & $16.9 \%$ & $6.3 \%$ & 3.46 & 4 & 91.2 & $\begin{array}{c}0.0003 \\
1\end{array}$ \\
\hline $\begin{array}{lr}\text { Training } & \text { programs } \\
\text { offer many benefits } \\
\text { for } & \text { trained } \\
\text { employees } & \text { after } \\
\text { IPO } & \\
\end{array}$ & $32.4 \%$ & 53.5 & $7 \%$ & $6.3 \%$ & $0.7 \%$ & 4.11 & 2 & 43.1 & $\begin{array}{c}0.0000 \\
1\end{array}$ \\
\hline $\begin{array}{l}\text { The company is } \\
\text { keen to train all } \\
\text { employees } \\
\text { different } \\
\text { departments after } \\
\text { IPO }\end{array}$ & $10.6 \%$ & $44.4 \%$ & $19 \%$ & $18.3 \%$ & $7.7 \%$ & 3.32 & 6 & 142.2 & $\begin{array}{c}0.0000 \\
02\end{array}$ \\
\hline $\begin{array}{l}\text { Employees apply } \\
\text { what they learn in } \\
\text { training programs } \\
\text { after IPO }\end{array}$ & $8.5 \%$ & $48.6 \%$ & $26.1 \%$ & $12 \%$ & $4.9 \%$ & 3.44 & 5 & 59.4 & $\begin{array}{c}0.0000 \\
12\end{array}$ \\
\hline $\begin{array}{l}\text { There is fairness in } \\
\text { distributing training } \\
\text { opportunities to the } \\
\text { employees of the } \\
\text { company after IPO }\end{array}$ & $4.2 \%$ & $33.8 \%$ & $33.1 \%$ & $17.6 \%$ & $11.3 \%$ & 3.02 & 7 & 90.8 & $\begin{array}{c}0.0000 \\
04\end{array}$ \\
\hline $\begin{array}{l}\text { The company seeks } \\
\text { to develop the skills } \\
\text { of its employees } \\
\text { after IPO }\end{array}$ & $10.6 \%$ & $52.8 \%$ & $18.3 \%$ & $12 \%$ & $6.3 \%$ & 3.49 & 3 & 49.1 & $\begin{array}{c}0.0000 \\
01\end{array}$ \\
\hline
\end{tabular}

\section{Regression Analysis of Dependent Variable and Training}

Linear regression was applied to the collected data, in which:

$\mathrm{Y}=$ is the dependent variable (retention and continue in the company)

$\mathrm{X} 2=$ the first independent variable (training)

Table 10 illustrates the results of the simple linear regression, the relation between the dependent variable and independent variable, training.

The results showed that training affects retention and the intention to continue in the company; the correlation coefficient was 0.21 , which indicated that there is a positive relation between retention and the intention to continue in the company and training. The results of a $t$-test confirmed the association between the two variables, which supported the second hypothesis. The $\mathrm{R}^{2}$ value indicated that training affected retention and the intention to continue in the company by $4.5 \%$.

Table 10. Regression analysis of the effect of training

\begin{tabular}{|c|c|c|c|c|c|}
\hline $\mathbf{B}_{\mathbf{0}}$ & $\mathbf{B}_{\mathbf{1}}$ & $\mathbf{r}$ & $\mathbf{R}^{\mathbf{2}}$ & $\boldsymbol{t}$-value & $\boldsymbol{p}$-value \\
\hline 28.4 & 0.167 & 0.21 & 0.045 & 2.6 & 0.011 \\
\hline
\end{tabular}

Table 11 below presents the descriptive statistics for the third factor, promotion, and showed that it is a critical factor that motivates employees to continue working in the organisation. The first important statement was "Having opportunities for promotion encourages employees to continue with the company," with a mean of 4.34. This result indicated that the availability of promotional opportunities in oil companies encourages employees to 
continue their employment. This was followed by the statement, "The promotion system requires diligence and discipline at work," with a mean of 3.82. This result indicates that the study sample individuals agreed that promotion at work requires effort and diligence from the employees as well as a complete discipline. The statement, "There is very little chance of a promotion at my job," ranked third with a mean of 3.34, while the statement, "The administration is keen to develop the promotion system," ranked fourth with a mean of 3.29.

The statement "Satisfied with my chances of being promoted," ranked fifth with a mean of 3.03. The statement "The company is clear and understandable for employees," ranked sixth with a mean of 2.92. The statement, "I feel the fairness of company's job promotion system," ranked last with a mean of 2.90 .

The results shown in Table 11 indicate that most of the participants in the survey agreed with the phrases about the training factor, and their agreement with the positive phrases was higher than that with the negative phrases. This indicates that promotion had a positive effect on the employees' retention.

Further, the Chi-squared test result showed that there were no statistically significant differences between the respondents' opinions, which supported the third hypothesis, "Promotion policy correlates with the employees' turnover intentions."

Table 11. Descriptive statistics of promotion

\begin{tabular}{|c|c|c|c|c|c|c|c|c|c|}
\hline Statement & $\begin{array}{c}\text { Strongly } \\
\text { agree }\end{array}$ & Agree & $\begin{array}{c}\text { Neither } \\
\text { agree } \\
\text { nor } \\
\text { disagree }\end{array}$ & Disagree & $\begin{array}{l}\text { Strongly } \\
\text { disagree }\end{array}$ & Mean & Rank & $\begin{array}{c}\text { Chi-square } \\
\text { d }\end{array}$ & $\begin{array}{c}p \text {-valu } \\
\text { e }\end{array}$ \\
\hline $\begin{array}{l}\text { There is very little chance } \\
\text { of a promotion at my job } \\
\text { after IPO }\end{array}$ & $14.1 \%$ & $36.6 \%$ & $24.6 \%$ & $18.3 \%$ & $6.3 \%$ & 3.34 & 3 & 37.1 & $\begin{array}{c}0.0000 \\
1\end{array}$ \\
\hline $\begin{array}{l}\text { Satisfied with my chances } \\
\text { of being promoted after } \\
\text { IPO }\end{array}$ & $6.3 \%$ & $36.6 \%$ & $21.1 \%$ & $25.4 \%$ & $10.6 \%$ & 3.03 & 5 & 41.3 & $\begin{array}{c}0.0000 \\
2\end{array}$ \\
\hline $\begin{array}{l}\text { I feel the fairness of the } \\
\text { company's job promotion } \\
\text { system after IPO }\end{array}$ & $8.5 \%$ & $28.9 \%$ & $22.5 \%$ & $24.6 \%$ & $15.5 \%$ & 2.90 & 7 & 18.4 & 0.0015 \\
\hline $\begin{array}{l}\text { The promotion system } \\
\text { requires diligence and } \\
\text { discipline at work after } \\
\text { IPO }\end{array}$ & $30.3 \%$ & $40.1 \%$ & $14.8 \%$ & $11.3 \%$ & $3.5 \%$ & 3.82 & 2 & 62.9 & $\begin{array}{c}0.0000 \\
1\end{array}$ \\
\hline $\begin{array}{l}\text { Having opportunities for } \\
\text { promotion encourages } \\
\text { employees to continue } \\
\text { with the company after } \\
\text { IPO }\end{array}$ & $53.5 \%$ & $35.2 \%$ & $4.9 \%$ & $4.9 \%$ & $1.4 \%$ & 4.34 & 1 & 153.2 & $\begin{array}{c}0.0000 \\
0\end{array}$ \\
\hline $\begin{array}{l}\text { The administration is keen } \\
\text { to develop the promotion } \\
\text { system after IPO }\end{array}$ & $14.1 \%$ & $37.3 \%$ & $21.8 \%$ & $17.6 \%$ & $9.2 \%$ & 3.29 & 4 & 37.8 & $\begin{array}{c}0.0000 \\
13\end{array}$ \\
\hline $\begin{array}{l}\text { The promotion system in } \\
\text { the company is clear and } \\
\text { understandable for } \\
\text { employees after IPO }\end{array}$ & $7.7 \%$ & $32.4 \%$ & $22.5 \%$ & $19 \%$ & $18.3 \%$ & 2.92 & 6 & 22.3 & 0.0014 \\
\hline
\end{tabular}




\section{Regression Analysis of the Dependent Variable and Promotion}

A linear regression was applied to the data collected, in which:

$\mathrm{Y}=$ is the dependent variable (retention and continue in the company)

$\mathrm{X} 3$ = the first independent variable (promotion)

Table 12 presents the results of the simple linear regression, the relation between the dependent variable and independent variable, promotion.

The results revealed that promotion affects retention and the intention to continue in the company. The correlation coefficient was 0.23 , which indicated that there is a positive relation between retention, the intention to continue in the company, and promotion. A $t$-test showed the positive association between the two variables, which supported the third hypothesis. The $\mathrm{R}^{2}$ value indicated that promotion affected retention and the intention to continue in the company by $5.3 \%$.

Table 12. Regression analysis of the effect of promotion

\begin{tabular}{|c|c|c|c|c|c|}
\hline $\mathbf{B}_{\mathbf{0}}$ & $\mathbf{B}_{\mathbf{1}}$ & $\mathbf{r}$ & $\mathbf{R}^{\mathbf{2}}$ & $\boldsymbol{t}$-value & $\boldsymbol{p}$-value \\
\hline 28.2 & 0.183 & 0.23 & 0.053 & 2.8 & 0.006 \\
\hline
\end{tabular}

\section{Discussion}

Many companies compete to attract talent by offering employees the best compensation systems, but they find it very difficult to implement this because of other expenses related to taxes and training. Although a salary is necessary, it is not the most important factor for job candidates, and the employee can be compensated with a lower salary when a system is in place to reward excellent performance.

In this paper, the study's respondents indicated that the financial compensation the company provided attracted them to join the company, which is inconsistent with Ramlall's (2004) outcomes. The respondents showed that the work environment is not as important as the monetary compensation, and they felt confident about their opportunity to increase their salary, which is in line with Chelladurai's (2006) finding.

In this time of informatics and fast changes, the preparation business has gotten exceptionally significant. It requires explicit information sources that must likewise satisfy explicit quality guidelines. We can build up the right idea of preparing, and revise the old ideas so that preparation isn't seen just as a cost but rather as a high-esteem speculation. Spectators of the work market perceive the need to execute worker preparation programs just to keep up the underlying capabilities important to save representatives' essential abilities and create and improve those abilities. Through the business, items, and the administrations organisations give to its labourers. We note that huge organisations working in the petrol field have given them incredible significance, which is the reason such organisations spend a huge amount on preparing its different projects, as they know about the extraordinary advantages that they will obtain from preparing and building up their representatives.

In this study, participants believed that training programs are one of the most important factors that affect their intention to remain with their company, as employees receive many benefits when the company seeks to develop their skills. This outcome is consistent with Koster et al. (2011), who found training and development to be key elements of job satisfaction.

The promotion also motivates workers to do their best, which in line with Abu Bakr's (2006) finding. This result shows that production will increase in the short run. If companies establish a good promotion system, employees are encouraged to remain with them. While having opportunities for promotion encourages employees to continue with the company, the promotion system requires diligence and discipline at work.

The results of a simple linear regression found that there is an association between the dependent variable (retention and continue in the company) and the independent variables of financial compensation, training, and promotion, all three of which positively affect employees' retention in the company.

\section{Conclusion}

This study identified financial compensation's influence on employees' turnover intention in the energy sector. The results of the survey showed that financial compensation, training, and promotion policy are correlated positively with employees' intentions to remain in their organisation. These results emphasise that companies in the energy sector should give more attention to these three factors to motivate their employees to remain in their 
companies. Further, training programs should be comprehensive and allow all employees an equal opportunity to participate in them. The companies must adopt a clearer system for promotion as well and make the system accessible to all employees.

Indeed, this study might be the basis for further studies that may include more intrinsic and extrinsic motivation factors covering other industries and more organisations. This study, however, only investigated the factors that affect employees' turnover intention in a single petroleum company. Hence, this research should be extended to other companies in the energy sector, as well as to private and government organisations, to provide a broader view of the factors that influence employees' turnover intention.

\section{References}

Abu, B., \& Mustafa, M. (2006). Human resources, introduction to achieving competitive advantage. Alexandria, University House.

Alam, S. M. (2015). Factors affecting job satisfaction, motivation and turnover rate of medical promotion officer (MPO) in pharmaceutical industry: A study based in Khulna City. Asian Business Review, 1(2), 126-131. https://doi.org/10.18034/abr.v1i2.324

Anderson, P. M., Meyer, B. D., Pencavel, J., \& Roberts, M. J. (1994). The extent and consequences of job turnover. Brookings papers on economic activity. Microeconomics, 1994, 177-248. https://doi.org/10.2307/2534731

Arnold, H. J., \& Feldman, D. C. (1982). A multivariate analysis of the determinants of job turnover. Journal of Applied Psychology, 67(3), 350. https://doi.org/10.1037/0021-9010.67.3.350

Bader, B., Schuster, T., \& Dickmann, M. (2015). Special issue of The International Journal of Human Resource Management: Danger and risk as challenges for HRM: How to manage people in hostile environments. The International Journal of Human Resource Management, 26(15), 2015-2017. https://doi.org/10.1080/09585192.2015.1038116

Balčiūnaitienè, A., Barvydienè, V., \& Petkevičiūtè, N. (2015). Career development in cross-cultural environment. Management of Organisations: Systematic Research, 66, 7-17. https://doi.org/10.7220/MOSR.1392.1142.2013.66.1

Bartlett, K. R. (2001). The relation between training and organisational commitment: A study in the health care field. Human Resource Development, 12, 333-352. https://doi.org/10.1002/hrdq.1001

Boxall, P., Hutchison, A., \& Wassenaar, B. (2015). How do high-involvement work processes influence employee outcomes? An examination of the mediating roles of skill utilization and intrinsic motivation. The International Journal of Human Resource Management, 26(13), 1737-1752. https://doi.org/10.1080/09585192.2014.962070

Campbell, D. (2008). Nonfinancial performance measures and promotion-based incentives. Journal of Accounting Research, 46(2), 297-332. https://doi.org/10.1111/j.1475-679X.2008.00275.x

Carney, K. (1998). How businesses can reduce high employee turnover. Inc., 47.

Chan, S. H., \& Mai, X. (2015). The relation of career adaptability to satisfaction and turnover intentions. Journal of Vocational Behavior, 89, 130-139. https://doi.org/10.1016/j.jvb.2015.05.005

Chan, S. H., Chok, S. Y., Lae, S. Y., Lam, A. C., \& Lee, C. Y. (2017). The impact of perceived organisational support, job satisfaction, leader-member exchange (LMX) and work-life balance on employees' turnover intention in manufacturing industry, Malaysia (doctoral dissertation, UTAR).

Chandler, G., \& G. McEvoy (2000). Human resource management, TQM and firm performance in small and medium-sized enterprises. Entrepreneurial Theory and Practice, 25, 45-58. https://doi.org/10.1177/104225870002500105

Chelladurai, P. (2006). Human resource management in sport and recreation (2nd ed.). Champaign, IL: Human Kinetics.

Chruden, H. J., \& Sherman, A. W. (1972). Personal management. South-Western, Philippine.

Cotton, J. L., \& Tuttle, J. M. (1986). Employee turnover: A meta-analysis and review with implications for research. Academy of Management Review, 11(1), 55-70. https://doi.org/10.5465/amr.1986.4282625

Cropanzano, R., \& Mitchell, M. S. (2005). Social exchange theory: An interdisciplinary review. Journal of Management, 31(6), 874-900. https://doi.org/10.1177/0149206305279602

Dalziel, P. (2010). Leveraging Training Skills Development in SMEs: An Analysis of Canterbury Region, New 
Zealand. Local Economic and Employment Development (LEED). Retrieved from http://www.oecd.org/dataoecd/7/39/45538500.pdf

Du Preez, R., \& Bendixen, M. T. (2015). The impact of internal brand management on employee job satisfaction, brand commitment and intention to stay. International Journal of Bank Marketing, 33(1), 78-91. https://doi.org/10.1108/IJBM-02-2014-0031

Ferris, G. R., \& Rowland, K. M. (1981). Leadership, job perceptions, and influence: A conceptual integration. Human Relations, 34(12), 1069-1077. https://doi.org/10.1177/001872678103401204

Finnegan, R. P. (2010). Rethinking retention in good times and bad: Breakthrough ideas for keeping your best workers. Boston, MA, Davies-Black.

Gardner, D. G., Van Dyne, L. V., \& Pierce, J. L. (2004). The effects of pay level on organisation-based self-esteem and performance: A field study. Journal of Occupational and Organisational Psychology, 77(3), 307-322. https://doi.org/10.1348/0963179041752646

Ghansah, E. (2011). The role of employee retention on job performance: A case study of Accra Brewery. Company Limited, Accra.

Ghosh, D., \& Gurunathan, L. (2015). Do commitment based human resource practices influence job embeddedness and intention to quit? IIMB Management Review, 27(4), 240-251. https://doi.org/10.1016/j.iimb.2015.09.003

Guest, D. E. (2002). Human resource management, corporate performance and employee wellbeing: Building the worker into HRM. The Journal of Industrial Relations, 44, 335-358. https://doi.org/10.1111/1472-9296.00053

Harris, J., \& Brannick, J. (1999). Finding \& keeping great employees (Vol. 314). New York: Amacom.

Hausknecht, J. P., Rodda, J. M., \& Howard, M. J. (2008). Targeted employee retention: Performance-based and job-related differences in reported reasons for staying. Working Paper Series, Cornell University, School of Industrial and Labor Relations, Centre for Advanced Human Resource Studies, Working Paper 06-08.

Heneman, H. G., \& Judge, T. A. (2000). Incentives and motivation. In S. Rynes \& [3] B. Gerhart (Eds.), Compensation in organizations: Progress and prospects, 61-103. San Francisco, CA: New Lexington Press.

Ichniowski, C., Shaw, K., \& Prennushi, G. (1997). The effect of human resource management practices on productivity. American Economic Review, 87, 291-313.

Igbaria, M., \& Greenhaus, J. H. (1992). Determinants of MIS employees' turnover intentions: A structural equation model. Communications of the ACM, 35(2), 34-49. https://doi.org/10.1145/129630.129631

Irshad, M. (2000). Factors affecting employee retention: Evidence from literature review. Abasyn. Journal of Social Science, 4(1), 84-102.

Jacobs, E., \& Roodt, G. (2007). The development of a knowledge sharing construct to predict turnover intentions. Aslib Proceedings, 59, 229-248. Emerald Group Publishing Limited. https://doi.org/10.1108/00012530710752034

Jehanzeb, K., Hamid, A. B., \& Rasheed, A. (2015). What is the role of training and job satisfaction on turnover intentions? International Business Research, 8(3), 208. https://doi.org/10.5539/ibr.v8n3p208

Ji Sung, K., \& Senryu, R. (2017). Employee satisfaction with work-life balance policies and organisational commitment: A Philippine study. Work-Life balance policies and organisational commitment, 261(37), 260-276. https://doi.org/10.1002/pad.1794

Kar, B. P., Sharma, A., \& Borah, S. B. (2011). Attrition in SMEs: The causes. European Journal of Business and Management, 3(5), 5-16.

Katsikea, E., Theodosius, M., \& Morgan, R. E. (2015). Why people quit: Explaining employee turnover intentions among export sales managers. International Business Review, 24(3), 367-379. https://doi.org/10.1016/j.ibusrev.2014.08.009

Khalid, K., \& Nawab, S. (2018). Employee participation and employee retention in view of compensation. SAGE Open, 8(4). https://doi.org/10.1177/2158244018810067

Kontoghiorghes, C., \& Bryant, N. (2004). Exploring employee commitment in a service organisation in the health care insurance industry. Organisation Development Journal, 22, 59-73.

Koster, F., de Grip, A., \& Fouarge, D. (2011). Does perceived support in employee development affect personnel 
turnover? The International Journal of Human Resource Management, 22, 2403-2418. https://doi.org/10.1080/09585192.2011.584404

Kuvaas, B., \& Dysvik, A. (2009) Perceived investment in employee development, intrinsic motivation and work performance. Human Resource Management Journal, 19, 217-236. https://doi.org/10.1111/j.1748-8583.2009.00103.x

Kuvaas, B., Buch, R., \& Dysvik, A. (2018). Individual variable pays for performance, incentive effects, and employee motivation. In annual meeting of the Academy of Management, Chicago, USA. https://doi.org/10.5465/AMBPP.2018.12393abstract

Kwenin, D. O., Muathe, S., \& Nzulwa, R. (2013). The influence of employee rewards, human resource policies and job satisfaction on the retention of employees in Vodafone. Ghana Limited. European Journal of Business and Management, 5(12), 1-8.

Lau, P. Y., McLean, G. N., Lien, B. Y., \& Hsu, Y. C. (2016). Self-rated and peer-rated organisational citizenship behaviour, affective commitment, and intention to leave in a Malaysian context. Personnel Review, 45(3), 569-592. https://doi.org/10.1108/PR-04-2014-0083

Lee, C. H., \& Bruvold, N. T. (2003). Creating value for employees: Investment in employee development. The International Journal of Human Resource Management, 14, 986-1000. https://doi.org/10.1080/0958519032000106173

Mansoor, S., Shah, F. T., ur Rehman, A., \& Tayyaba, A. (2015). Impact of training and development on organisation performance with mediating role of intention to quit as human resource quality cost. European Online Journal of Natural and Social Sciences, 4(4), 787

Mardiyanti, O. A., Utami, H. N., \& Prasetya, A. (2018). The effect of financial compensation and non-financial compensation on employees' performance through job satisfaction as an intervening variable (study on permanent employees of PT Citra Perdana Kendedes in Malang, East Java). Jurnal Administrasi Bisnis, 62(1), 135-144.

Michael, B., Prince, A. F., \& Chacko, A. (2016). Impact of compensation package on employee retention. Clear International Journal of Research in Commerce \& Management, 7(10).

Mobley, W. H. (1982). Some unanswered questions in turnover and withdrawal research. Academy of Management Review, 7(1), 111-116. https://doi.org/10.5465/amr.1982.4285493

Mostafa, A. M., Gould-Williams, J. S., \& Bottomley, P. (2015). High-Performance human resource practices and employee outcomes: The mediating role of public service motivation. Public Administration Review, 75(5), 747-757. https://doi.org/10.1111/puar.12354

Nawab, S., \& Bhatti, K. K. (2011). Influence of employee compensation on organisational commitment and job satisfaction: A case study of educational sector of Pakistan. International Journal of Business and Social Science, 2(8), 25-32.

Neves, P., Almeida, P., \& Velez, M. J. (2018). Reducing intentions to resist future change: Combined effects of commitment-based HR practices and ethical leadership. Human Resource Management, 57(1), $249-261$. https://doi.org/10.1002/hrm.21830

Nishii, L. H., Lepak, D. P., \& Schneider, B. (2008). Employee attributions of the "why" of practices: Their effects on employee attitudes and behaviors, and customer satisfaction. Personnel Psychology, 61, 503-545. https://doi.org/10.1111/j.1744-6570.2008.00121.x

Palwasha, B., Ashfaq, A., \& Abdul, H. A. M. (2018). The impact of training and development and supervisors support on employees retention in academic institutions in Pakistan: The moderating role of the work environment, Gadjah Mada. International Journal of Business, 20(1), 113-131. https://doi.org/10.22146/gamaijb.24020

Palwasha, et al. (2017). The impact of compensation and promotional opportunities on employee retention in academic institutions: The moderating role of work environment. International Journal of Economic Perspectives, 11(1), 378-391.

Peltokorpi, V., Allen, D. G., \& Froese, F. (2015). Organisational embeddedness, turnover intentions, and voluntary turnover: The moderating effects of employee demographic characteristics and value orientations. Journal of Organisational Behavior, 36(2), 292-312. https://doi.org/10.1002/job.1981

Peterson, S. L. (2004). Toward a theoretical model of employee turnover: A human resource development perspective. Human Resource Development Review, 3(3), 209-227. 
https://doi.org/10.1177/1534484304267832

Ramlall, S. (2003). Organisational application managing employee retention as a strategy for increasing organisational competitiveness. Applied H.R.M. Research, 8(2), 63-72.

Ramlall, S. (2004). A review of employee motivation theories and their implications for employee retention within organisations. Journal of American Academy of Business, 5(1/2), 52-63.

Ratnasari, S. L., \& Sutjahjo, G. (2020). The effect of job satisfaction, organisational culture, and leadership on employee performance. Annals of Tropical Medicine and Health, 23, 231-329. https://doi.org/10.36295/ASRO.2020.231329

Reem, S., \& Ammoura (2014). The impact of employees' moral factors on turnover intentions (unpublished master thesis). Case study on Syriatel Telecom Company, Damascus University, Syria.

Saira, et al. (2014). Impact of financial and non-financial rewards on employee motivation. Middle-East Journal of Scientific Research, 21(10), 1776-1786.

Shukla, S., \& Sinha, A. (2013). Employee turnover in banking sector: Empirical evidence. IOSR Journal of Humanities and Social Science, 11(5), 57-61. https://doi.org/10.9790/0837-1155761

Singh, S., \& Dixit, P. P. (2011). Employee retention: The art of keeping the people who keep you in business. VSRD International Journal of Business \& Management Research, 1(7), 441- 448.

Smeenk, S. G., R. N. Eisinga, J. C. Telken, \& J. A. C. M. Doorewaard (2006). The effects of HRM practices and antecedents on organisational commitment among university employees. International Journal of Human Resource Management, 17, 2035-2054. https://doi.org/10.1080/09585190600965449

Walker, J. W. (2001). Zero defections? Human Resource Planning, 24(1), 6-8.

Williams, M. L., \& Dreher, G. F. (1992). Compensation system attributes and applicant pool characteristics. Academy of Management Journal, 35(3), 571-595. https://doi.org/10.5465/256487

Wright, P. M., \& Boswell, W. R. (2002). Desegregating HRM: A review and synthesis of micro and macro human resource management research. Journal of Management, 28, 247-276. https://doi.org/10.1177/014920630202800302

Wright, P. M., \& Nishii, L. H. (2007). Strategic HRM and organisational behaviour: Integrating multiple levels of analysis (CAHRS Working Paper \#07-03). Ithaca, NY: Cornell University. Retrieved from http://digitalcommons.ilr.cornell.edu/cahrswp/468

Wright, P. M., McMahan, G. C., \& McWilliams, A. (1994). Human resources and sustained competitive advantage: A resource-based perspective. International Journal of Human Resource Management, 5(2), 301-326. https://doi.org/10.1080/09585199400000020

Yamao, S., \& Sekiguchi, T. (2015). Employee commitment to corporate globalization: The role of English language proficiency and human resource practices. Journal of World Business, 50(1), 168-179. https://doi.org/10.1016/j.jwb.2014.03.001

Yankeelov, P. A., Barbee, A. P., Sullivan, D., \& Antle, B. F. (2009). Individual and organisational factors in job retention in Kentucky's child welfare agency. Children and Youth Services Review, 31(5), 547-554. https://doi.org/10.1016/j.childyouth.2008.10.014

Yousaf, S., Latif, M., Aslam, S., \& Saddiqui, A. (2014). Impact of financial and non-financial rewards on employee motivation. Middle-East Journal of Scientific Research, 21(10), 1776-1786.

Zaffane, R. M. (1994). Understanding employee turnover. Int. J. Manpower, 15(9), 22-33. https://doi.org/10.1108/01437729410074182

Zareen, M., Razzaq, K., \& Ramzan, M. (2013). Impact of employee retention on performance: moderating role of employee psychological perception toward retention plan. Interdisciplinary Journal of Contemporary Research in Business, 4(10), 822-833.

Zewail, M. H. (1998). Personnel management. Amman: Majdalawi Publishing House.

\section{Copyrights}

Copyright for this article is retained by the author(s), with first publication rights granted to the journal.

This is an open-access article distributed under the terms and conditions of the Creative Commons Attribution license (http://creativecommons.org/licenses/by/4.0/). 